\title{
Bacterial utilization of glucose in the water column from eutrophic to oligotrophic pelagic areas in the eastern North Atlantic Ocean
}

\author{
Armand Bianchi ${ }^{*}$, France Van Wambeke, Jean Garcin \\ Microbiologie Marine (C.N.R.S.-I.N.S.U., UPR 223), Université de la Méditerranée, Faculté des Sciences de Luminy, Case 907,13288 \\ Marseille cedex 9, France
}

Received 17 June 1996; accepted 21 October 1996

\begin{abstract}
Vertical profiles of glucose utilization rates were compared at three sampling stations in the eastern part of the tropical North Atlantic Ocean. The investigation area was along $20-21^{\circ} \mathrm{N}$ and the three sampling sites, characterised by differences in their primary productivity, were located at $18^{\circ} \mathrm{W}, 21^{\circ} \mathrm{W}$ and $31^{\circ} \mathrm{W}$. In the superficial waters, maximum $\left(V_{\max }\right)$ glucose utilization (respiration plus incorporation) depended on the nutritional load being 20 -fold higher in the eutrophic, compared to the oligotrophic zone. Due to these variations, natural turnover times for this labile compound were approximately 1 day in the eutrophic area, and up to 435 days in the oligotrophic area. Bacterial activity showed a steep decline immediately below the mixed layer in the mesotrophic and eutrophic areas and below the deep chlorophyll maximum in the oligotrophic area. Discrepancies between microbial activities in the three areas decreased with increasing depth: at depths below $250 \mathrm{~m}$ potential utilization rates of glucose were similar whatever the nutrient richness of the photic layer. Nevertheless, the distribution of microbial activities through the whole water column depended greally on the productivity of superficial waters. In nutrient-rich areas $73 \%$ of glucose utilization activity was realized in the productive upper layer, whereas only $4 \%$ was metabolized at depths below $250 \mathrm{~m}$. Conversely, in the oligotrophic area, more than $40 \%$ of the glucose utilized in the whole water column was processed in the intermediate and deep-water masses. Integration of $V_{\max }$ values for the whole water column, suggested potential carbon fluxes due to bacterial utilization of glucose of 6 and $34 \mathrm{mg} \mathrm{C} \mathrm{m}^{-2} \mathrm{~d}^{-1}$ in the oligotrophic and eutrophic areas, respectively. The fate of the metabolised carbon depended on the nutrient availability. In the mixed-water layer the glucose respiration percentage $(\% \mathrm{R})$ increased from $30 \%$ in nutrient-rich areas to $60 \%$ under oligotrophic conditions, moreover $\% \mathrm{R}$ increased with depth. This infers that at lower nutritional loads, a greater proportion of highly labile compounds is used for energetic purposes, and therefore return to the inorganic carbon pool, but with very low turnover rates. (C) 1998 Elsevier Science B.V.
\end{abstract}

Keywords: bacteria; deep sea; organic carbon; mineralization

\footnotetext{
${ }^{*}$ Corresponding author. E-mail: micromar@luminy.univ-mrs.fr
}

\section{Introduction}

Utilization of dissolved organic compounds by heterotrophic bacteria is an important process in the control of biogeochemical cycles in the ocean. Anal- 
yses of substrate utilization have been applied to appreciate the metabolic activity of heterotrophic bacteria on the dissolved organic carbon (DOC) bulk in diverse marine ecosystems (Vaccaro, 1969; Williams, 1970; Andrews and Williams, 1971; Cahet and Jacques, 1976; Griffiths et al., 1977; Wright, 1978; Malone et al., 1991; Bianchi and Garcin, 1993, 1994). But, as noted by Ducklow et al. (1993), relatively little is still known concerning the dynamics of the bacterial-DOC link in the open sea. Diverse operational strategies are possible to quantify the role played by bacterioplankton in the transformation of the DOC bulk (Wright, 1984). The most commonly used methods estimate bacterial production by measurement of ${ }^{3} \mathrm{H}$-thymidine or ${ }^{3} \mathrm{H}$ leucine incorporation into nucleic acid, and/or the measurement of bacterial utilization of labelled organic compounds, such as amino acids or glucose.

With the Eumeli cruise the France Joint Global Ocean Flux Study (France-JGOFS) program provided an opportunity to measure microbial activities in pelagic waters in parallel with a suite of other measurements to estimate the fluxes of organic carbon between the surface and the water-sediment boundary layer (see an overview in Jacques, 1993; Morel, 1996). The general strategy for this program was to estimate the energy and matter flow in the water column under different trophic conditions in the eastern part of the tropical North Atlantic Ocean. In this paper we present an estimation of microbial heterotrophic activity determined by the measurement of glucose metabolism in the whole water column, under different trophic conditions ranging from eutrophic to oligotrophic. Bacterial utilization of glucose is discussed in relation to bacterial biomass and production, water mass distribution, seawater temperature and nutrient load.

\section{Material and methods}

\subsection{Study areas}

Samples were collected during the Eumeli IV cruise (May-June, 1992). The investigation area was along $20-21^{\circ} \mathrm{N}$, with three sampling sites located at $18^{\circ} \mathrm{W}, 21^{\circ} \mathrm{W}$ and $31^{\circ} \mathrm{W}$. The former site, 90 miles off the Mauritanian coast, was eutrophic due to the West
African coastal upwelling. The two other sites, located in the area of the Cape Verde Frontal Zonc, were mesotrophic and oligotrophic, respectively (Jacques, 1993).

\subsection{Sampling and microbial activity measurements}

Each site was studied over a few days to investigate intra-site variability of all parameters, and seawater samples were collected during two hydrocasts at each site. Water samples were collected in 10-1 Go-Flo bottles which were acid-washed $(10 \% \mathrm{HCl}$ in distilled water), alcohol-sterilised $(50: 50, \mathrm{v} / \mathrm{v})$ and rinsed with sterile distilled water. Samples were collected at 5, 20, 30, 40, 50, 75, 150, 250, 500, $1000,1500,2000,2500,3000,3500$, and $4000 \mathrm{~m}$ depths. Samples were transferred to 2-1 sterile polycarbonate flasks and immediately processed. A solution of D-(U- $\left.{ }^{14} \mathrm{C}\right)$-glucose, specific activity $10.6 \mathrm{GBq}$ $\mathrm{mmol}^{-1}$ (Amersham Corp.), was added to give a final concentration of $8.5 \mathrm{n} M$. Samples were incubated in the dark, at in-situ temperature $\left( \pm 1^{\circ} \mathrm{C}\right)$ for time course experiments.

Subsamples (100 to $250 \mathrm{ml}$ according to depths and sites) were taken at zero-time (control), 0.5, 1, and 1.5 or at $0,3,6,12$ and $24 \mathrm{~h}$, for superficial and deep-waters, respectively. At the end of each incubation period subsamples were fixed by the addition of formalin saturated with sodium tetraborate ( $1 \%$ final concentration, $\mathrm{v} / \mathrm{v}$ ). Bacterial cells were collected by vacuum filtration onto $0.2 \mu \mathrm{m}$ polycarbonate filters (Nuclepore) prewashed with an unlabelled glucose solution. Filters were washed twice with 5 $\mathrm{ml}$ of $0.2 \mu \mathrm{m}$ filtered seawater. The filtrate was acidified $(1 \mathrm{ml} \mathrm{HCl}, 6 \mathrm{~N})$ and released ${ }^{14} \mathrm{C} \mathrm{CO}_{2}$ was flushed using $\mathrm{N}_{2}$ blowing (100 ml min ${ }^{-1}$ ) for 30 min. $\mathrm{CO}_{2}$ was trapped in two serial scintillation vials containing each $9 \mathrm{ml}$ of a cocktail of ethanolaminemethanol-ACS scintillation liquid (ratio 1:1:7, $\mathrm{v} / \mathrm{v}$ ). Filters and vials containing the ${ }^{14} \mathrm{C} \mathrm{CO}_{2}$ were counted aboard the research vessel on a Packard 1600 TR liquid scintillation counter. ${ }^{14} \mathrm{C}$-glucose incorporation, ${ }^{14} \mathrm{C}$-glucose respiration, and ${ }^{14} \mathrm{C}$-glucose utilization rates (sum of incorporated and respired label) and the respiration percentage (\% $\mathrm{R}$, percentage of the respired to the total ${ }^{14} \mathrm{C}$-glucose utilization) were computed from these data as:

$v=$ slope $/($ dpm added $) \times A$ 
where $v=$ rate of respiration (or incorporation) of ${ }^{14} \mathrm{C}$-glucose, in pmol $\mathrm{C}^{-1} \mathrm{~h}^{-1}$, slope = the slope of the regression line of the dpm increase in the subsamples against time, in $\mathrm{dpm} \mathrm{h}^{-1}$; dpm added is the amount of dpm added in the subsample, and $A$ is the labelled glucose added, in pmol $\mathrm{C}^{-1}$ ). Samples were corrected for blanks as the time zero was included in the regression.

For selected samples we realized also multi-concentration method experiments using four different ${ }^{14} \mathrm{C}$-glucose concentrations $(4.5,9,45$ and $90 \mathrm{nM})$, using $40 \mathrm{ml}$ seawater volumes. In these cases only glucose incorporation was measured. Despite some limitations imposed by the method (Gocke, 1977; Krambeck, 1979), some kinetic parameters can be estimated using this approach: $V_{\max }$, a theoretical maximum incorporation rate, $\left(K_{\mathrm{t}}+S_{\mathrm{n}}\right)$, the sum of transport constant and natural substrate concentration of the water sample, and $T_{\mathrm{t}}$ the turnover time of glucose, i.e. the number of days required for the natural community for incorporation of a quantity of glucose equal to its natural concentration in the water sample (Gocke, 1977).

\section{Results}

\subsection{Response to label concentrations}

The kinetic parameters deduced from the Lineweaver-Burk plots of the concentration kinetics are presented in Table $1 . K_{\mathrm{t}}+S_{\mathrm{n}}$ values ranged between 1.5 and $11 \mathrm{n} M$. The $V_{\text {IIIax }}$ values obtained by concentration kinetic experiments are in the same range as the ${ }^{14} \mathrm{C}$ - glucose incorporation rates obtained with $8.5 \mathrm{n} M$ added. $V_{8.5} / V_{\max }$ ratio varied from 0.5 (in oligotrophic conditions) to 2 at $1000 \mathrm{~m}$ depth in the eutrophic site. Small sample volumes and short incubation periods during the multi-concentration assays resulted in very low dpm counts for deep samples, and explained unrealistic $V / V_{\max }$ ratios higher than 1.

The main interest of the multi-concentration method was to check whether or not the added glucose used in the single concentration method (time course experiment) corresponded to saturation conditions. Our data showed that rates obtained with $8.5 \mathrm{n} M$ labelling concentration was always more than $70 \%$ of the $V_{\max }$ (Table 2) for all the samples we studied, excluded the surface layer of the eutrophic area. Therefore, the metabolic rates measured for glucose in these superficial nutrient-rich waters should be considered as underestimated $V_{\max }$ values. For all other samples, whatever the site, the labelling concentration used in the time series approached a saturating concentration; therefore ${ }^{14} \mathrm{C}$-glucose utilization rates measured by the single concentration method (time kinetics) should be considered as the maximum utilization rates of glucose at in-situ temperature $\left(V_{\max }\right)$, and not as actual in-situ rates.

\subsection{Vertical distributions}

In the three study areas, both incorporation and respiration rates showed a marked maximum value in the subsurface layer. Inside one site, both respira-

Table 1

Results of concentration kinetics

\begin{tabular}{rlccc}
\hline Depth $(\mathrm{m})$ & $V_{8.5} / V_{\max }$ & $V_{\max }\left(\mathrm{pmol}\right.$ gluc. $\left.\mathrm{l}^{-1} \mathrm{~h}^{-1}\right)$ & $T_{\mathrm{t}}$ (days) & $\left(K_{\mathrm{t}}+S_{\mathrm{n}}\right) \mathrm{n} M \mathrm{glucose}$ \\
\hline 5 (eutro) & 0.53 & 167 & 1.2 & 4.7 \\
20 (eutro) & 0.7 & 225 & 0.8 & 4.6 \\
75 (eutro) & 0.76 & 17.4 & 5.5 & 2.3 \\
250 (eutro) & 0.73 & 1.1 & 423 & 11.2 \\
1000 (eutro) & 2 & 0.1 & 435 & 1.5 \\
5 (oligo) & 0.76 & 3.7 & 63 & 5.6 \\
20 (oligo) & 1.1 & 4.1 & 17 & 1.7 \\
\hline
\end{tabular}

$V_{\max }:$ turnover times $\left(T_{1}\right)$ and $\left(K_{\mathrm{t}}+S_{\mathrm{n}}\right)$ in eutrophic (eutro) and oligotrophic (oligo) areas.

$V_{8.5} / V_{\max } \%$ : ratio of rates obtained with $8.5 \mathrm{n} M^{14} \mathrm{C}$ glucose added (concentration used routinely in the time series experiments) and $V_{\max }$. 
Table 2

${ }^{14} \mathrm{C}$-glucose assimilation (pmol $\mathrm{C}^{-1} \mathrm{~h}^{-1}$ )

\begin{tabular}{|c|c|c|c|c|c|c|c|c|c|c|c|c|}
\hline \multirow[t]{2}{*}{ Depth (m) } & \multicolumn{4}{|c|}{ Oligotrophic area } & \multicolumn{4}{|c|}{ Mesotrophic area } & \multicolumn{4}{|c|}{ Eutrophic area } \\
\hline & $T\left({ }^{\circ} \mathrm{C}\right)$ & set $\mathrm{O} 1$ & set $\mathrm{O} 2$ & $\overline{01 / 02}$ & $\overline{T\left({ }^{\circ} \mathrm{C}\right)}$ & set M1 & set M2 & $\mathrm{M} 1 / \mathrm{M} 2$ & $T\left({ }^{\circ} \mathrm{C}\right)$ & set E1 & set E2 & $\mathrm{E} 1 / \mathrm{E} 2$ \\
\hline 5 & 23.0 & 7.5 & 9.2 & 0.81 & 21.0 & 938.4 & 707.0 & 1.33 & 18.5 & 577.2 & 1351.4 & 0.43 \\
\hline 20 & 22.9 & 29.7 & 85.9 & 0.35 & 21.0 & 700.7 & 594.5 & 1.18 & 18.5 & 1313.8 & 1839.3 & 0.69 \\
\hline 30 & 22.8 & 28.4 & 52.6 & 0.54 & 21.0 & 1151 & 477.8 & 2.41 & 18.0 & 1276.3 & 982.2 & 1.30 \\
\hline 40 & 22.6 & 26.1 & 44.2 & 0.59 & 21.0 & 610.4 & 278.8 & 2.19 & 18.0 & 1457.7 & 1057.3 & 1.38 \\
\hline 50 & 22.5 & 11.9 & 36.1 & 0.33 & 21.0 & 283.0 & 68.2 & 4.15 & 18.0 & 994.7 & 1094.8 & 0.91 \\
\hline 75 & 22.3 & 7.0 & 62.2 & 0.11 & 18.5 & 92.3 & 18.3 & 5.04 & 18.0 & 66.0 & - & - \\
\hline 100 & 22.0 & 25.7 & 78.8 & 0.26 & 16.5 & 21.8 & 20.4 & 1.07 & 17.0 & 16.1 & 39.6 & 0.41 \\
\hline 150 & 21.0 & - & 10.4 & - & 15.0 & 7.9 & 5.6 & 1.41 & 16.0 & 7.0 & - &.- \\
\hline 250 & 17.5 & 3.5 & 4.6 & 0.76 & 13.5 & 2.9 & 7.2 & 0.40 & 13.5 & 2.7 & 3.7 & 0.73 \\
\hline 500 & 12.0 & 3.4 & 0.3 & 11.3 & 9.5 & 0.5 & 0.9 & 0.55 & 11.0 & 0.4 & 1.9 & 0.21 \\
\hline 1000 & 7.0 & - & 0.2 & - & 6.5 & 1.7 & 0.3 & 5.66 & 6.5 & 0.4 & 0.6 & 0.66 \\
\hline 1500 & 4.0 & - & - & - & 5.0 & 0.3 & 0.1 & 3.00 & - & 0.4 & 0.6 & 0.66 \\
\hline 2000 & 2.9 & 0.14 & - & - & 2.0 & 0.3 & - & - & - & - & 0.3 & - \\
\hline 2500 & 2.5 & 0.1 & - & - & 2.0 & 0.2 & - & - & - & - & - & - \\
\hline 3000 & 2.0 & 0.09 & - & - & 2.0 & 0.2 & - & - & - & - & - & - \\
\hline 3500 & 2.0 & 0.1 & - & - & - & - & - & - & - & - & - & - \\
\hline 4000 & 2.0 & 0.11 & - & - & - & - & - & - & - & - & - & - \\
\hline
\end{tabular}

Two sets of data and corresponding ratio of the two sets of data for each sampling area.

$T$ : in-situ temperature.

tion and incorporation rates frequently changed by a factor of 2 within a $48 \mathrm{~h}$ period (Tables 2 and 3 ). These variations were similar to the range observed by Dandonneau (1994) for primary production data during the same campaign. However, the oligotrophic site is clearly distinct from the two other

Table 3

${ }^{14} \mathrm{C}$-glucose respiration (pmol $\mathrm{CO}_{2} \mathrm{l}^{-1} \mathrm{~h}^{-1}$ ) at the three sampling areas

\begin{tabular}{|c|c|c|c|c|c|c|c|c|c|}
\hline \multirow[t]{2}{*}{ Depth (m) } & \multicolumn{3}{|c|}{ Oligotrophic area } & \multicolumn{3}{|c|}{ Mesotrophic area } & \multicolumn{3}{|c|}{ Eutrophic area } \\
\hline & set $\mathrm{O} 1$ & set $\mathrm{O} 2$ & $01 / 02$ & set Ml & set M2 & $\mathrm{M} 1 / \mathrm{M} 2$ & set E1 & set E2 & $\mathrm{E} 1 / \mathrm{E} 2$ \\
\hline 5 & 86.0 & 5.0 & 1.15 & 362.5 & 340.9 & 1.06 & 512.6 & 378.5 & 1.35 \\
\hline 20 & 88.6 & 73.7 & 1.20 & 212.9 & 270.2 & 0.79 & 593.1 & 610.8 & 0.97 \\
\hline 30 & 107.0 & 44.3 & 2.42 & 419.8 & 250.6 & 1.68 & 568.7 & 452.1 & 1.26 \\
\hline 40 & 74.6 & 40.7 & 1.83 & 213.9 & 129.1 & 1.66 & 681.9 & 478.4 & 1.43 \\
\hline 50 & 74.5 & 39.3 & 1.90 & 75.5 & 42.7 & 1.77 & 430.5 & 453.7 & 0.95 \\
\hline 75 & 76.0 & 45.0 & 1.69 & 49.1 & 13.8 & 3.56 & 47.1 & - & - \\
\hline 100 & 11.9 & 48.8 & 0.24 & 20.9 & 8.3 & 2.51 & 14.3 & 96.8 & 0.15 \\
\hline 150 & - & 6.2 & - & 40.3 & 2.5 & 16.10 & 23.0 & - & - \\
\hline 250 & 6.0 & 1.5 & 4.0 & 4.8 & 6.5 & 0.74 & 8.7 & 0.9 & 9.66 \\
\hline 500 & - & 0.4 & - & 8.2 & 0.7 & 11.71 & 0.1 & 1.5 & 0.06 \\
\hline 1000 & - & 0.1 & - & 1.8 & 0.5 & 3.60 & 4.9 & 0.4 & 12.25 \\
\hline 1500 & - & 0.5 & - & 0.9 & 1.2 & 0.75 & 4.1 & 0.8 & 5.13 \\
\hline 2000 & 3.7 & - & - & 0.1 & - & - & - & 0.2 & - \\
\hline 2500 & 3.3 & - & - & 0.2 & - & - & - & - & - \\
\hline 3000 & 1.9 & - & - & 0.4 & - & - & - & - & - \\
\hline 3500 & 2.6 & - & - & - & - & - & - & - & - \\
\hline 4000 & 1.9 & - & - & - & - & - & - & - & - \\
\hline
\end{tabular}

Two sets of data and corresponding ratio of the two sets of data for each sampling area. 


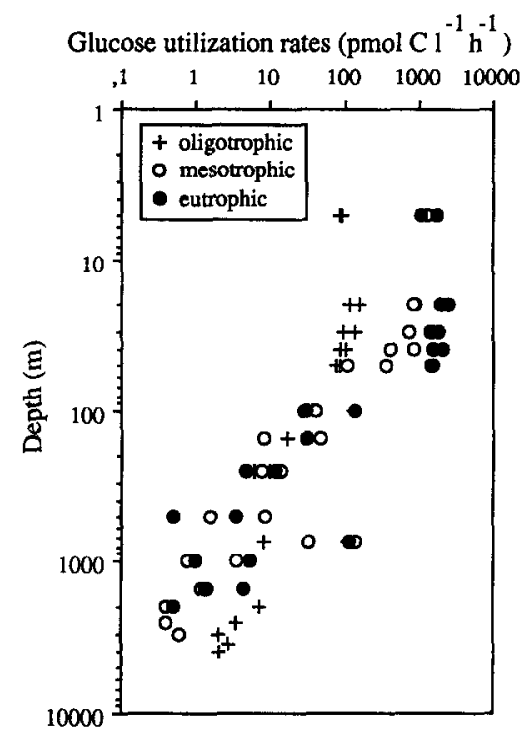

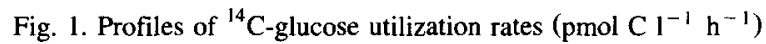
in the three nutritionally characterized areas.

sites, with low values in the euphotic zone, and a deepening of the higher values down to $100 \mathrm{~m}$, following the deep chlorophyll maximum. For deeper layers the difference between sites decreased, with values down to $0.1 \mathrm{pmol} \mathrm{C}^{-1} \mathrm{~h}^{-1}$ for glucose assimilation and respiration rates.

Glucose utilization refers to the sum of glucose used by microbial populations for energetic (respiration) and for anabolic (incorporation) purposes. Below the photic zone glucose utilization drastically decreases on a logarithmic scale (Fig. 1). Thus it is evident that variations due to increasing depth surpass those due to day-to-day variations.

In the oligotrophic area, where the mixed layer was approximately $30 \mathrm{~m}$ thick (Taillez and Morel, 1994), the maximal utilization rate was in the 20-30 m layer, i.e. just above the thermocline. Below the thermocline the glucose utilization rate progressively decreased, and below the deep chlorophyll maximum $(100 \mathrm{~m})$ it drastically decreased, to be at $250 \mathrm{~m}$ only $5 \%$ of its maximal value.

In the mesotrophic area, glucose utilization rates reached maximum values in the upper layer and remained high in the $40 \mathrm{~m}$ thick mixed layer. Below the mixed layer, the utilization rate was $20 \%$ of the maximal value, and immediately below the thermocline it was only $7 \%$ of its maximal value.

Through all the thickness $(50 \mathrm{~m})$ of the mixed layer of the eutrophic area, the utilization rate was relatively high (at least $68 \%$ of its maximal value) and then decreased to be only $5 \%$ of the maximum at $75 \mathrm{~m}$.

Indeed, the thickness of the microbiologically most active water-layer varied with trophic conditions. In the eutrophic area this layer coincided with the $50 \mathrm{~m}$ deep mixed layer which is thicker than the photic layer (Taillez and Morel, 1994). Similarly in the oligotrophic area, the most active zone was not limited to the $40 \mathrm{~m}$ deep mixed layer, but is extended down to $100 \mathrm{~m}$, near to the deep chlorophyll maximum. In mesotrophic and eutrophic areas, low activities appeared very early in the water column. Values lower than $1 \%$ of the maximum uptake rate were already observed at a depth of $250 \mathrm{~m}$.

From $500 \mathrm{~m}$ depth, i.e. before entering in the North Atlantic Deep Water (NADW) located from $1200 \mathrm{~m}$ and below (Vangriesheim et al., 1993),

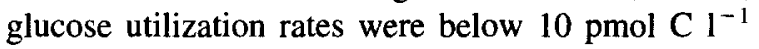
$\mathrm{h}^{-1}$, whatever the nutrient richness of the superficial layers.

Glucose utilization rate appears significantly correlated to bacterial productivity and bacterial numbers, whatever the site (Table 4).

Table 4

Spearman rank correlation coefficients $(R)$ for variables in the three studied water columns

\begin{tabular}{|c|c|c|c|c|c|c|}
\hline & \multicolumn{2}{|c|}{ Oligotrophic site } & \multicolumn{2}{|c|}{ Mesotrophic site } & \multicolumn{2}{|c|}{ Eutrophic site } \\
\hline & $R$ & $N$ & $R$ & $N$ & $R$ & $N$ \\
\hline Glucose uptake versus thymidine incorporation & $0.78^{* *}$ & 14 & $0.98^{* *}$ & 21 & $0.92^{* * *}$ & 20 \\
\hline Glucose uptake versus direct counts & $0.72^{* * *}$ & 20 & $0.95^{* * *}$ & 21 & $0.88^{* * *}$ & 20 \\
\hline
\end{tabular}

${ }^{* *} p<0.01 .{ }^{* * *} p<0.001 . N=$ number of samples. Direct counts and ${ }^{3} \mathrm{H}$-thymidine incorporation rates in the nucleic acid are data from Dufour and Torréton (pers. commun.) measured on the same water samples. 


\subsection{The respiration percentage $(R \%)$ in the water column}

Considering the very low activities observed, we checked if the duration of the time kinetic allowed to reach the isotopic equilibrium for the carbon pools $\left(\mathrm{CO}_{2}\right.$ and particulate), which is a necessary condition to measure properly glucose respiration rates (Williams, 1970). During the time course experiments, the respiration percentage of glucose was constant whatever the incubation period only when processing the most productive samples, i.e. all the samples collected in the eutrophic area and those collected in the upper layer of the mesotrophic area (data not shown). At the opposite, for all the samples collected in the oligotrophic area, and those collected deeper than $100 \mathrm{~m}$ in the mesotrophic area, the isotopic equilibrium of ${ }^{14} \mathrm{C}-\mathrm{CO}_{2}$ was not reached during the incubation period. Consequently, for these samples the respiration percentage could be underestimated.

In the mixed layer, most of the ${ }^{14} \mathrm{C}$-glucose was mainly used for bacterial biomass production (mean $\mathrm{R} \%=38.2$, Table 5), especially in the eutrophic and mesotrophic area (mean $\mathrm{R} \%=31 \%$ and 29.2 , respectively). Beneath the mixed layer, no differences were apparent between the three study areas. The glucose respiration percentage was highly variable (Table 5), regression analysis of $\mathrm{R} \%$ against depth showed a significant decrease only in oligotrophic site $(p=0.001)$. Nevertheless, in the three areas glucose utilization was exactly shared by bacteria between incorporation and respiration in the intermediate waters collected above $500 \mathrm{~m}$ depth (mean $\mathrm{R} \%=50.5$ ), and was based on an energetic metabolism into the NADW (mean $\mathrm{R} \%=68.8$, Table $5)$. In seven deep-water samples $R \%$ was nearby 90\%. In these cases, high glucose respiration percentages were due mainly to increased respiration rates (up to $4 \mathrm{pmol} \mathrm{C}^{-1} \mathbf{h}^{-1}$ ), as the incorporation rates were no lower than in other deep-water samples (0.1-0.2 pmol C $\left.1^{-1} \mathrm{~h}^{-1}\right)$. A so high $\mathrm{R} \%$ is surprising, but we did not reject these data as we examined all possible methodological artefacts: (i) an enrichment would increase simultaneously incorporation and respiration; (ii) bottle effect was rejected because the respiration measured was linear over time ( $r$ was always greater than 0.8 on the data set of the time kinetics); (iii) a possible contamination of the ${ }^{14} \mathrm{C}$-glucose batch was eliminated because these high respiration rates were observed in a series of samples where other data were in the usual range.

Table 5

Mean glucose respiration percentages

\begin{tabular}{|c|c|c|c|c|}
\hline$\% \mathrm{R}$ & Layer & Range & Mean \pm sd & $N$ \\
\hline \multirow[t]{3}{*}{ Eutrophic site } & $0-\operatorname{ML}(50 \mathrm{~m})$ & $21.9-47.0$ & $31 \pm 6$ & 10 \\
\hline & $0-250 \mathrm{~m}$ & $19.6-76.3$ & $40 \pm 18$ & 16 \\
\hline & $500-2000 \mathrm{~m}$ & $20.0-92.5$ & $54 \pm 27$ & 7 \\
\hline \multirow[t]{3}{*}{ Mesotrophic site } & $0-\mathrm{ML}(40 \mathrm{~m})$ & $23.3-34.4$ & $29 \pm 4$ & 8 \\
\hline & $0-250 \mathrm{~m}$ & $21.1-62.3$ & $37 \pm 15$ & 18 \\
\hline & $500-3000 \mathrm{~m}$ & $43.8-92.3$ & $62 \pm 22$ & 9 \\
\hline \multirow[t]{3}{*}{ Oligotrophic site } & $0-\mathrm{ML}(30 \mathrm{~m})$ & $35.2-92.0$ & $62 \pm 23$ & 6 \\
\hline & $0-250 \mathrm{~m}$ & $31.6-92.0$ & $56 \pm 22$ & 17 \\
\hline & $500-4000 \mathrm{~m}$ & $33.3-94.3$ & $78 \pm 24$ & 7 \\
\hline \multirow[t]{3}{*}{ All sites } & all $\mathrm{ML}$ & & $38 \pm 18$ & 24 \\
\hline & all interm $(\mathrm{ML}-500 \mathrm{~m})$ & & $50 \pm 21$ & 32 \\
\hline & all $>1000 \mathrm{~m}$ & & $69 \pm 24$ & 18 \\
\hline
\end{tabular}

All values in percentages. $M L=$ mixed layer $(50 \mathrm{~m}, 40 \mathrm{~m}$ and $30 \mathrm{~m}$ depth in the oligotrophic, mesotrophic and eutrophic sites, respectively); all interm. $=$ mean of all values for depths included between $\mathrm{ML}$ and $500 \mathrm{~m} . \mathrm{N}=$ number of samples. 
Table 6

Integrated bacterial ${ }^{14} \mathrm{C}$-glucose utilization and respiration $\left(\mathrm{mg} \mathrm{C} \mathrm{m} \mathrm{d}^{-2}\right)$ in the mixed layer, the photic and sub-photic layer (0-250 $\mathrm{m}$ ) and the whole water column (WWC) in the three nutritionally characterized areas

\begin{tabular}{|c|c|c|c|c|c|c|}
\hline \multirow[t]{2}{*}{ Layer } & \multicolumn{2}{|c|}{ Oligotrophic site } & \multicolumn{2}{|c|}{ Mesotrophic site } & \multicolumn{2}{|c|}{ Eutrophic site } \\
\hline & util. & $\% \mathrm{WWC}$ & util. & $\% \mathrm{WWC}$ & util. & $\% \mathrm{WWC}$ \\
\hline Mixed layer & 0.9 & 14 & 11.6 & 68 & 25.1 & 73 \\
\hline Photic and sub-photic & 3.7 & 59 & 15.5 & 90 & 32.9 & 96 \\
\hline \multirow[t]{2}{*}{ Whole water column } & 6.2 & 100 & 17.1 & 100 & 34.3 & 100 \\
\hline & resp. & $\% \mathrm{WWC}$ & resp. & $\% \mathrm{WWC}$ & resp. & $\% \mathrm{WWC}$ \\
\hline Mixed layer & 06 & 15 & 3.3 & 57 & 7.5 & 65 \\
\hline Photic and sub-photic & 2.1 & 54 & 4.8 & 82 & 10.6 & 91 \\
\hline Whole water column & 3.8 & 100 & 5.9 & 100 & 11.6 & 100 \\
\hline
\end{tabular}

Util. = glucose utilization $\left(\mathrm{mg} \mathrm{C} \mathrm{m} \mathrm{m}^{-2} \mathrm{~d}^{-1}\right)$; resp. $=$ glucose respiration $\left(\mathrm{mg} \mathrm{C} \mathrm{m} \mathrm{d}^{-1}\right) ; \%$ WWC $=$ relative contribution of some selected layers compared to the whole water column.

\subsection{Integration of glucose utilization and respiration in the water column}

Integrated glucose utilization rates were similar for the meso- and eutrophic areas, but clearly differed in the oligotrophic area (Table 6). In nutrientrich conditions, $73 \%$ of the glucose utilization for the whole water column occurred in the mixed layer, and only $4 \%$ was metabolised below $250 \mathrm{~m}$. Conversely, under oligotrophic conditions only $14 \%$ of total glucose utilization occurred in the mixed layer. Under oligotrophic conditions $46 \%$ of the mineralization of glucose, one of the most labile organic compounds (i.e. with a short turnover time in the upper productive layers, see below), took place at depths greater than $250 \mathrm{~m}$, in the intermediate and deep waters (Table 6).

\subsection{Glucose turnover time $\left(T_{t}\right)$}

As with the time series we were in conditions of substrate excess, turnover times were overestimated and not used here. We report only data from concentration kinetics ( $Y$ intercept of the Lineweaver-Burk plot, see methods). In the surface waters the turnover times were dependent on the nutritional status of the sampling area; in oligotrophic conditions the glucose $T_{t}$ varied between 17 and 63 days, compared to only one day under nutrient-rich conditions (Table 1). The turnover time increases with increasing depth, to reach more than 400 days below $250 \mathrm{~m}$.

\section{Discussion}

\subsection{Effect of the nutrient load on the microbial activity rates}

In the study area of the tropical North Atlantic Occan, primary production varies from 330 to 2250 $\mathrm{mg} \mathrm{C} \mathrm{m} \mathrm{m}^{-2} \mathrm{~d}^{-1}$ between oligotrophic and eutrophic sites, respectively (Dandonneau, 1994). The role of ambient temperature on microbial activity appears to be small compared to the effect of nutrient availability. In surface layers, despite a temperature difference of $5^{\circ} \mathrm{C}$ between oligotrophic $\left(\sim 23^{\circ} \mathrm{C}\right)$ and eutrophic $\left(\sim 18^{\circ} \mathrm{C}\right)$ waters above the thermocline, the bacterial community was clearly more active in the colder, but nutrient-rich area (Table 2). The bacterial communities perfectly adapt their metabolic rates to the nutritional load: the higher is the nutritional load, the faster is the bacterial uptake, due to both increase in bacterial numbers (Dufour and Torréton, 1996) and specific activity per cell (Table 7).

Despite the fact that the percentage of viable bacteria among the microscopically counted populations varies greatly (Bianchi and Giuliano, 1996), 
Table 7

Specific incorporation rates of glucose $\left(10^{-12} \mu \mathrm{g}\right.$ glucose bacterium $^{-1} \mathrm{~h}^{-1}$ ) in the mixed layer (ML), the photic and sub-photic layer $(0-250 \mathrm{~m})$ and the deeper layers in the three nutritionally characterized areas

\begin{tabular}{llllr}
\hline & Layer & Range & Mean \pm sd & $N$ \\
\hline Eutrophic site & $0-$ ML $(50 \mathrm{~m})$ & $5.0-17.2$ & $10.8 \pm 3.3$ & 10 \\
& $0-250 \mathrm{~m}$ & $0.24-17.2$ & $7.2 \pm 5.3$ & 16 \\
& $500-2000 \mathrm{~m}$ & $0.10-0.25$ & $0.17 \pm 0.06$ & 7 \\
Mesotrophic site & $0-$ ML $(40 \mathrm{~m})$ & $2.8-10.3$ & $7.1 \pm 2.2$ & 8 \\
& $0-250 \mathrm{~m}$ & $0.27-4.2$ & $3.8 \pm 3.4$ & 18 \\
& $500-3000 \mathrm{~m}$ & $0.05-0.24$ & $0.17 \pm 0.06$ & 6 \\
& & & & \\
Oligotrophic site & $0-$ ML (30 m) & $0.45-3.9$ & $1.7 \pm 1.3$ & 6 \\
& $0-250$ & $0.45-5.7$ & $1.7 \pm 1.4$ & 17 \\
& $500-4000$ & $0.20-0.29$ & $0.2 \pm 0.03$ & 7 \\
\hline
\end{tabular}

$N=$ number of samples.

glucose uptake rates appear significantly correlated with epifluorescence counts. However, fluctuations in bacterial numbers was not the unique source of variation in the glucose utilization rates, because (i) specific activity per cell increased also significantly from the oligotrophic to the eutrophic site in the upper layers, and (ii) in each site, decreased significantly from the surface to deeper layers (Table 7). The range of specific incorporation, corresponding to a $V_{\max }$ per bacterium for glucose incorporation $\left(0.05-17.2 \cdot 10^{-12} \mu \mathrm{g} \mathrm{cell}^{-1} \mathrm{~h}^{-1}\right)$ fell into the lowest values of $V_{\max }$ per bacterium cited, even after respiration correction (Wright, 1978; Goulder, 1979). The variations of $\log$ (bacterial counts) explained 93\% of the variations of $\log$ (glucose incorporation rates), but the variations of $\log$ (incorporation per cell) explained also $93 \%$ of $\log$ (glucose incorporation rates, data not shown), suggesting that specific activity and bacterial numbers participated equally to the variations of heterotrophic activity.

Williams and Gray (1970) established that heterotrophic populations of both estuarine and coastal waters area were able to accommodate within a period of 1-2 days to a 10-fold increase in amino acids concentration. In open-sea, bacterial production responds rapidly to variations in photosynthesis (Ducklow et al., 1993). Hoppe et al. (1993) observed that in the mesopelagic zone bacteria rapidly reacted to nutrient inputs fuelled by phytoplankton. The low turnover times we recorded in the upper layers indi- cate a rapid utilization of glucose and approach those measured by Andrews and Williams (1971) in the English Channel, and those observed by Rheinheimer et al. (1989) in the Baltic Sea. These data are in agreement with the conclusions of Kirchman et al. (1991) and Malone et al. (1991), that 10 to $40 \%$ of the DOC pool can be turned over by bacteria on a time scale of days. In oligotrophic conditions high regeneration rates allow phytoplankton to grow at rates very close to nutrient-saturated rates in the subtropical area, as it was observed here (Claustre and Marty, 1995). Consequently, in the superficial layers of the ocean the bacterial communities act as a filter for nutrients: excluding rapidly sinking particles, labile compounds would not pass through this biological filter. Therefore, in intermediate and deeper waters, the available labile compounds are probably locally produccd, rather than imported by diffusion from the photic zone.

In the mixed layer, most of the ${ }^{14} \mathrm{C}$-glucose uptake was used for assimilatory purposes (mean $\mathrm{R} \%$ $=38.2$, Table 5), similar to those recorded by Gillepsie et al. (1976) in Antarctic superficial waters and accordingly with the mean growth yield of $67 \%$ observed on ${ }^{14} \mathrm{C}$-glucose by Williams (1970) in the Western Mediterranean and in the North East Atlantic. Furthermore, in the mixed layer, to fuel their metabolic processes bacteria need to spend proportionally more energy to substrate utilization in oligotrophic conditions than in eutrophic ones (Table 5). In the water column the proportion of organic carbon devoted to energy yielding reactions appears inversely proportional to the nutrient load, and as observed by Cahet and Jacques (1976) the part used as an energy source increases with depth (Table 5). This increase of the respiration percentage in the most oligotrophic areas could be due to the maintenance energy. At very low nutrient concentration the metabolic processes due to the catabolic reactions necessary to keep the cell viable and therefore permanently used for purposes other than growth (Stanier et al., 1976) become relatively more important than in nutrient-rich conditions. Moreover, the observed differences between the respiration percentage in superficial and deep waters, and between nutrient-rich and nutrient-poor areas, are probably underestimated, since during the incubation period isotopic equilibrium for $\mathrm{CO}_{2}$ production was not 
attained in samples collected in the oligotrophic area and in those collected deeper than $100 \mathrm{~m}$ in the mesotrophic area.

In the two nutrient-rich areas, the depth-limit corresponding to $1 \%$ of the maximum uptake rate appeared at a depth of $250 \mathrm{~m}$, corresponding with the lowest recorded values of $\delta^{13} \mathrm{C}$ of $\Sigma \mathrm{CO}_{2}$ which mark the level of maximum regeneration rate (Pierre et al., 1994). We have previously observed (Bianchi and Garcin, 1993, 1994) that decompression of seawater samples collected at $1100 \mathrm{~m}$ depth causes a decrease in bacterial metabolism. However, there is no evidence that such an inhibitory effect could significantly affect samples collected at $250 \mathrm{~m}$ depth. Therefore, we can consider that the physiological stress due to decompression cannot explain the so dramatic decline of microbial activity observed in these waters.

In the deep water masses, discrepancies in glucose uptake rates between nutrient-rich and nutrientpoor areas were insignificant compared to the daily variations. Pierre et al. (1994) concluded from $\delta^{13} \mathrm{C}$ of $\Sigma \mathrm{CO}_{2}$ measurements, that at depths greater than $900 \mathrm{~m}$, organic matter remineralization was independent of surface productivity levels and occurs at similar and very low rates in the oligotrophic, mesotrophic and eutrophic zones. This homogeneity of microbial activity corresponds to the homogeneous NADW present at all three sites at depths greater than $2000 \mathrm{~m}$ (Pierre et al., 1994).

\subsection{Sources of limitation in deep waters}

In the NADW, temperatures are below $5^{\circ} \mathrm{C}$, these conditions could partially explain the slowing down of microbial activities in the deep water masses. Excepted for the superficial and for the deep waters, glucose incorporation per cell decreased on a logarithmic scale with the inverse of the in-situ temperature. Within the pool of data showing a linear regression in Fig. 2 (in intermediate waters where temperature varied between 5 and $17^{\circ} \mathrm{C}$ ) the apparent $Q_{10}$ is around 30 , i.e. much higher than the true $Q_{10}$ values generally cited: 2.5 (Kirchman et al., 1995) or 2.6 ohtained in September 1991 in the same area with bacterial production data (Fernandez, Garnier, Van Wambeke, pers. commun.). Consequently, the temperature can not be considered as the major factor

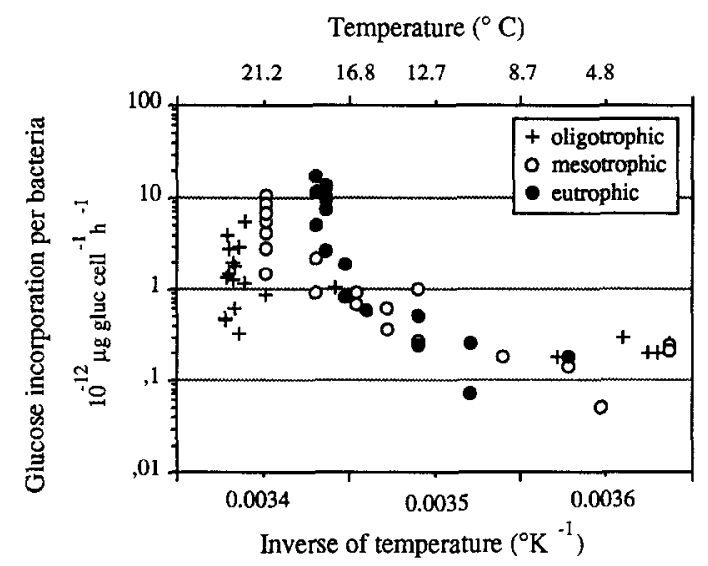

Fig. 2. Relationship of specific incorporation of glucose per bacterium $\left(10^{-12} \mu \mathrm{g}\right.$ glucose bacterium $\left.{ }^{-1} \mathrm{~h}^{-1}\right)$ and temperature (inverse of temperature, $\mathrm{K}^{-1}$ ) in the three nutritionally characterized areas.

limiting bacterial activity in any layer of the water column. We have previously observed in deep Mediterranean waters, where the temperature is never lower than $13^{\circ} \mathrm{C}$ (i.e. $10^{\circ} \mathrm{C}$ warmer than the NADW), bacterial densities (Bianchi and Giuliano, 1996) and glucose utilization rates (Bianchi and Garcin, 1994) in the same ranges as those measured in the NADW. The glucose utilization rates measurcd in the NADW, between 0.1 and a few pmol $\mathrm{C}^{-1} \mathrm{~h}^{-1}$, seem to be within the normal range in deep-sea waters (Poremba, 1994). The lowest values we measured appear close to the detection limit imposed by the ${ }^{14} \mathrm{C}$ method. Moreover, due to the day-to-day variations, differences observed within this set of deep-sea samples cannot be considered as really significant.

The uptake rates we observed into the intermediate and deep water masses are likely to be underestimates, due to the inhibitory effect of sample decompression on the microbial activity measurements (Bianchi and Garcin, 1993, 1994; Poremba, 1994). Moreover, the increase of the respiration percentage with increasing depth could be due to the physiological stresses associated with the decompression of samples during retrieval (Bianchi and Garcin, 1993, 1994; Turley, 1993; Poremba, 1994). Additionally, as marine bacteria are expected to be primarily limited by dissolved organic matter availability as an energy source (Kirchman, 1990), we could hypothesize that the addition of a very labile organic com- 
pound to the deep DOC bulk could cause a comctabolism effect. Since addition of labelled glucose may energise the bacteria allowing the anabolic use of other refractory organic compounds which would otherwise be resistant to bacterial attack.

\subsection{Glucose uptake versus other microbial parame- ters}

Glucose is generally considered as a highly labile organic compound; however, it cannot be considered as a universal indicator of bacterial metabolism (Kuparinen, 1984). Since depending on local specific diversity, the part of the bacterial community actually able to utilize glucose as sole carbon and energy source varies from 0 to $100 \%$ of the culturable strains (Bensoussan and Bianchi, 1983). Moreover, the rate of net bacterial utilization of in-situ total dissolved carbohydrates could be 10 to 100 -fold greater than the glucose utilization rates determined by the single-concentration method (Burney, 1986).

Integration of measured $V_{\max }$ over the whole water column thickness in the oligotrophic area leads to the calculation of a potential bacterial utilization of glucose of $6.2 \mathrm{mg} \mathrm{C} \mathrm{m}^{-2} \mathrm{~d}^{-1}$, i.e. approximately $2 \%$ of the photosynthetic production measured during this campaign by Dandonneau (1994), in the same area. These data can be compared with the annual flux oxidized by micro-organisms calculated by Andrews and Williams (1971) in the English Channel to be $2.6 \mathrm{~g} \mathrm{C} \mathrm{m}^{-2}$ for glucose, corresponding to $1.5 \%$ of the total carbon fixed. We extrapolated the glucose respiration rates measured in the oligotrophic water column to the worlds oceans (surface $360.8 \cdot 10^{6} \mathrm{~km}^{2}$, average depth $3500 \mathrm{~m}$, Bowden, 1975). Potential mineralization rates of glucose represented $0.5 \mathrm{Gt} \mathrm{C}$ per year, i.e. only $1.7 \%$ of the total annual primary production of the world ocean, based on the estimation of a total production of $30 \mathrm{Gt}$ cited by Berger et al. (1989). Due to the lack of data concerning the natural glucose concentration in seawater, and proportion of C-glucose utilization against all other labile carbon sources, it is difficult to refer these glucose $V_{\max }$ data to the actual bacterial metabolism in the worlds oceans. Nevertheless, $40 \%$ of the glucose mineralization process could take place at depths deeper than $1000 \mathrm{~m}$. Consequently these data show that in an oligotrophic area, corresponding to the most common nutritional conditions in the worlds oceans, the metabolic role of deep-sea bacteria in the geochemical cycling of nutrients is far from inconspicuous.

\section{Acknowledgements}

We thank Patrick Buat-Menard, cruise leader, the officers and crew of R.V. L'Atalante for their support during the Eumeli IV cruise. We acknowledge P. Dufour and J.P. Torréton (ORSTOM, Papeete) for providing bacterial counts and bacterial production data. Helpful comments and language improvements by P.J. leB. Williams and an anonymous reviewer were greatly appreciated. This research has been supported by the Institut National des Sciences de l'Univers (INSU), JGOFS-France program.

\section{References}

Andrews, P., Williams, P.J.LeB., 1971. Heterotrophic utilization of dissolved organic compounds in the sea, III. Measurement of the oxidation rates and concentrations of glucose and amino acids in sea water. J. Mar. Biol. Assoc. U.K. 51, 111-125.

Bensoussan, M., Bianchi, A., 1983. Distribution et activité catabolique potentielle des communautés bactériennes des eaux et des sédiments profonds prélevés sur diverses marges continentales. In: Combaz, A. (Ed.), Géochimie Organique des Sédiments Marins d'Orgon à Misedor. Editions CNRS, Paris, pp. 39-72.

Berger, W.H., Smetacek, V.S., Wefer, G., 1989. Ocean productivity and paleoproductivity-An overview. In: Berger, W.H., Smetacek, V.S., Wefer, G. (Eds.), Productivity of the Ocean: Present and Past. Wiley, Chichester, pp. 1-34.

Bianchi, A., Garcin, J., 1993. In stratified waters the metabolic rate of deep sea bacteria decreases with decompression. Deep Sea Res. 40, 1703-1710.

Bianchi, A., Garcin, J., 1994. Bacterial response to hydrostatic pressure in seawater samples collected in mixed-water and stratified-water conditions. Mar. Ecol. Prog. Ser. 111, 137141.

Bianchi, A., Giuliano, L., 1996. Enumeration of viable bacteria in marine pelagic environment. Appl. Environ. Microbiol. 62, 174-177.

Bowden, K.F., 1975. Oceanic and estuarine mixing processes. In: Riley, J.P., Skirrow, G. (Eds.), Chemical Oceanography, Vol. 1, 2nd ed. Academic Press, London, pp. 1-41.

Burney, C.M., 1986. Bacterial utilization of total in situ dissolved carbohydrate in offshore waters. Limnol. Oceanogr. 31, 427431.

Cahet, G., Jacques, G., 1976. Assimilation du glucose dans la zone de divergence de Méditerranée Nord-Occidentale. Int. Rev. Ges. Hydrobiol. 61, 649-658. 
Claustre, H., Marty, J.C., 1995. Specific phytoplankton biomasses and their relation to primary production in the tropical North Atlantic. Deep-Sea Res. I 42, 1475-1493.

Dandonneau, Y., 1994. Incubations de ${ }^{14} \mathrm{C}$ in situ au cours des campagnes Eumcli 3 et Eumcli 4. In: Morel, A. (Ed.), Premiers Résultats des Campagnes EUMELI. Jt. Global Ocean Flux Study, France, Rep. 19, p. 101.

Ducklow, H.W., Kirchman, D.L., Quinb, H.L., Carlson, C.A., Dam, H.G., 1993. Stocks and dynamics of bacterioplankton carbon during the spring bloom in the eastern North Atlantic Ocean. Deep-Sea Res. 40, 245-263.

Dufour, P., Torréton, J.P., 1996. Bottom-up and top-down control of bacterioplankton from eutrophic to oligotrophic sites in the northeastern tropical Atlantic Ocean. Deep-Sea Res. I 43, 1305-1320.

Gillepsie, P.A., Morita, R.Y., Jones, L.P., 1976. The heterotrophic activity for amino acids, glucose and acetate in Antarctic waters. J. Oceanogr. Soc. Jpn. 32, 74-82.

Gocke, K., 1977. Comparison of methods for determining the turnover times of dissolved organic compounds. Mar. Biol. 42, $131-141$

Goulder, R., 1979. $V_{\max }$ per bacterium and turnover rate per bacterium for glucose mineralization in natural waters. Current Microbiol. 2, 365368.

Griffiths, R.P., Hayasaka, S.S., McNamara, T.M., Morita, R.Y., 1977. Comparison between two methods of assaying relative microbial activity in marine environments. Appl. Environ. Microbiol. 34, 801-805.

Hoppe, H.G., Ducklow, H., Karrasch, B., 1993. Evidence for dependency of bacterial growth on enzymatic hydrolysis of particulate organic matter in the mesopelagic ocean. Mar. Ecol. Prog. Ser. 93, 277-283.

Jacques, G., 1993. Observations on the pelagic system in the tropical Atlantic at $20^{\circ} \mathrm{N}$ (The EUMELI program). Ann. Inst. Océanogr. 69, 9-14.

Kirchman, D.L., 1990. Limitation of bacterial growth by dissolved organic matter in the subarctic Pacific. Mar. Ecol. Prog. Ser. $62,47-54$

Kirchman, D.L., Suzuki, Y., Garside, C., Ducklow, H.C., 1991. High turnover rates of dissolved organic carbon during a spring phytoplankton bloom. Nature 352, 612-614.

Kirchman, D.L., Rich, J.H., Barber, R.T., 1995. Biomass and biomass production of heterotrophic bacteria along $140^{\circ} \mathrm{W}$ in the equatorial Pacific: Effect of temperature on the microbial loop. Deep-Sea Res. II 42, 603-619.

Krambeck, C., 1979. Applicability and limitations of the Michaelis-Menten equation in microbial ecology. Arch. Hydrobiol. Beih. Ergebn. Limnol. 12, 64-76.

Kuparinen, J., 1984. Glucose assimilation: its contribution to carbon flux in the pelagial and use in monitoring heterotrophic activity. Arch. Hydrobiol. Beih. Ergebn. Limnol. 19, 15-24.
Malone, T.C., Ducklow, H.D., Peele, E.R., Pike, S.R., 1991. Picoplankton carbon fluxes in Chesapeake Bay. Mar. Ecol. Prog. Ser. 78, 11-22.

Morel, A., 1996. An ocean flux study in eutrophic, mesotrophic and oligotrophic situations: the EUMELI program. Decp-Sea Res. I 43, 1185-1190.

Pierre, C., Vangriesheim, A., Laube-Lenfant, E., 1994. Variability of water masses and of organic production-regeneration systems as related to eutrophic, mesotrophic and oligotrophic conditions in the northeast Atlantic Ocean. J. Mar. Syst. 5, $159-170$.

Poremba, K., 1994. Impact of pressure on bacterial activity in water columns situated at the European continental margin. Neth. J. Sea Res. 33, 29-35.

Rheinheimer, G., Gocke, K., Hoppe, H.-G., 1989. Vertical distribution of microbiolugical and hydrographic-chemical parameters in different areas of the Baltic Sea. Mar. Ecol. Prog. Ser. 52, 55-70.

Stanier, R.Y., Adelberg, A.E., Ingraham, J., 1976. The Microbial World. Prentice Hall, Englewood Cliffs, N.J., 871 pp.

Taillez, D., Morel, A., 1994. Hydrologie, autres paramètres de base, représentativité des trois sites. In: Morel, A. (Ed.), Premiers Résultats des Campagnes EUMELI. Jt. Global Ocean Flux Study, France, Rep. 19, pp. 3-10.

Turley, C.M., 1993. The effect of pressure on leucine and thymidine incorporation by free-living bacteria and by bacteria attached to sinking oceanic particles. Deep-Sea Res. 40 , 2193-2206.

Vaccaro, R.F., 1969. The response of natural microbial populations in seawater to organic enrichment. Limnol. Oceanogr. $14,726-735$

Vangriesheim, A., Pierre, C., Laube, E., 1993. Hydrological conditions in the EUMELI area in the NE tropical Atlantic: water masses, variability of productivity regeneration and of particle load. Ann. Inst. Océanogr. 69, 15-20.

Williams, P.J.LeB., 1970. Heterotrophic utilization of dissolved organic compounds in the sea, I. Size distribution of populations and relationship between respiration and incorporation of growth substrates. J. Mar. Biol. Assoc. U.K. 50: 859-870.

Williams, P.J.LeB., Gray, R.W., 1970. Heterotrophic utilization of dissolved organic compounds in the sea, II. Observations on the responses of heterotrophic marine populations to abrupt increases in amino acids concentration. J. Mar. Biol. Assoc. U.K. 50: $871-881$.

Wright, R.T., 1978. Measurement and significance of specific activity in the heterotrophic bacteria of natural waters. Appl. Environ. Microbiol. 36, 297-305.

Wright, R.T., 1984. Dynamics of pools of dissolved organic carbon. In: Hobbie, J.E., Williams, P.J.LeB. (Eds.), Heterotrophic Activity in the Sea. Plenum, New York, pp. 121154. 